\title{
ロボットのための超音波センシング 一その限界と今後への期待
}

Ultrasonic Sensing for Robots

- Current Limitation and Future Expectation-

油田 信 一***筑波大学機能工学系

Shin'ichi Yuta* * Institute of Engineering Mechanics and Systems, University of Tsukuba

\section{1. ロボットのための超音波センシング}

超音波とは波長が短く周波数の高い音波である。音波と は媒質中を圧力の変化により伝播する疎密波である，ロボッ トのセンシングでは空気中を伝播する超音波が利用される. 媒質が空気であっても，水やあるいは固体であっても，波 が伝播する原理は同じである。したがって，空気中のロボッ トの超音波センシングは，水中の魚群の探知機や体内を探 る超音波診断装置あるいは物体の非破壊検査などと同様の 音響的原理に基づく，しかし，伝播媒質が異なると，伝播 速度（音速）は大きく異なり，また，媒質によって音響イ ンピーダンスも大幅に異なるため, 他の音響学的手法とは 独立した技術が必要である。

音波の空気中の伝播速度は, 音速としてょく知られてい るとおり, $t$ を気温（度）として

$$
v_{0}=331+0.5 t[\mathrm{~m} / \text { 秒 }]
$$

である．また，気体中では媒質の密度が低く，波長の短い波 はほとんど伝播しない.このため, 数十 $[\mathrm{cm}]$ から数 $[\mathrm{m}]$ の 領域でセンシングを行おうとすると, 利用できる超音波は 可聴音ギリギリの $15[\mathrm{kHz}$ （波長 $2.2[\mathrm{~cm}] ）$ から $100[\mathrm{kHz}]$ （波長 $3.4[\mathrm{~mm}]$ ）の範囲に限られる.

ちなみに，可聴領域がセンシングに利用されない理由は， 波長が長いため分解能の良い計測ができないこと，および, センシングのために可聴音を発生させると，まわりの人に とって騒がしいためであろう。

\section{1 パルスエコー法}

ある点から超音波パルスを空気中に向けて発射したとき， その波は送波器の形状と波長によって決まる指向性をもっ て球面状に拡散しつつ伝播する。この波面が伝播していく 空間中に何らかの物体があると, その物体と空気の音速や 音響インピーダンスの差異により, 波面に反射と屈折が生

原稿受付 2002 年 4 月 10 日

キーワード : Ultrasonic Sensing, Sonar, Pulse-echo Method, Acoustic Measurement

*テ305-8573つくば市天王台

*Tsukuba-shi, Ibaraki
じる．空気と固体物体の音響インピーダンスは大幅に異な るため，超音波は物体の表面でほとんど反射し，反射点を 音源としてさらに拡散しつつ伝播する，反射波の波面は物 体表面上の各点での反射波が干涉しつつ重ね合わさったも のとなる。この反射波を送波器と同じ位置にある超音波受 波器で再び検出して電気信号に変換する。このとき，送波 してから受波するまでの時間が超音波の物体までの往復伝 播時間である．それを超音波の音速で割れば，送受波器か ら物体までの距離が求められる。

検出された反射波は，送波器と受波器の向きを中心とし て指向角（市販のデバイスでは $20^{\circ}$ 程度）の領域内にある 物体からの反射と考えられる。 そこで, 送受波器の向きの， 伝播時間に対応する距離の位置に，音波を反射させる物体 があると判断する。これが超音波パルスエコー法の原理で ある。

この原理に基づくセンサは極めて簡単なハードウェアで 実現できる．空気中の音速は電子回路の動作速度に比べて はるかに遅いので，反射波の検出までの時間をマイクロ秒 の精度で測定すれば $0.17[\mathrm{~mm}]$ の精度で反射点までの距離 が測れる.したがって, 超音波の送波と受波を行う超音波送 受波器をデバイスとして入手すれば，あとは簡単な電子回 路でセンサシステムが構成できる，超音波のセンサは，離 れた物体の幾何学的な位置をそれなりの精度で測定できる 便利なセンサであるにもかかわらず，ロボコンに参加する 高校生でも千円以下で自作できるセンサなのである.

\section{2 超音波トランスデューサ}

超音波センサで重要なデバイスは超音波を発射し反射波 を検出する送波器と受波器である。これらを超音波トラン スデューサと呼ぶ。一般に，トランスデューサは一つのデバ イスで送信器としても受信器としても利用できるため, パ ルスエコー法においては送波器と受信器を一つのトランス デューサに兼ねさせることが多い。よく使われるトランス デューサはバイモルフ型のセラミックの圧電素子（例えば 村田製作所製）や高分子フィルムに電極を蒸着したコンデ ンサ（例えばポラロイド社製）である。

トランスデューサにとって重要なパラメー夕は感度と共 振特性（周波数選択性）および指向性である。セラミック系 
の圧電デバイスは, 元来強い機械的共振特性を有する。し たがって，この種のトランスデューサを用いる場合は，送 信される超音波パルスはかなり狭帯域で，その波形は波数 10 波程度のバースト波形となる。このタイプのデバイスは その共振特性により実効的に高い感度を有する。一方コン デンサタイプのトランスデューサはひとまわり広い帯域を 有し，持続時間の短い波数が 2 3 波のパルスを発射して受 信する，逆に，七ンサが実用的な感度を持つためには，増 幅器に十分な増幅率を持たせる必要がある.

トランスデューサの指向性は，その開口の大きさと形状 によって決まる，トランスデューサの直径を $d$ とすると，そ の指向性の幅 $\theta$ は, ほほ

$$
\sin \theta=\lambda / d
$$

によって求められる。ここで入は超音波の波長である。こ の式は光も含めてあらゆる波について使われる式であるが， 空気中の超音波の場合は，周波数が低く波長が長いため, $\lambda$ と $d$ が同じオーダであることに注意を要する．例えばよく 使われる $40[\mathrm{kHz}]$ のトランスデューサでは，直径 $15[\mathrm{~mm}]$ に対し超音波の波長は $8.5[\mathrm{~mm}]$ であり, 鋭い指向性のビー ムを作ることは不可能である.

このようにトランスデューサの指向性は超音波の波長に 依存する。したがって，超音波が広帯域の場合はそれに含 まれる周波数成分ごとに指向性が異なることにも注意を要 する。

\section{2. 超音波パルスエコー法の特長と限界}

超音波パルスエコー法による物体の検出は簡単に実現で き，特に，赤外線などを用いたセンシングに比べ

（1）物体までの距離測定の精度が高い.

(2) $10[\mathrm{~m}]$ 近くのレンジまで測定可能である. という特長がある。このため, 利用価值は高く, 移動ロボッ トの環境センシングをはじめ，マニピュレーションにおけ る対象物や障害物の検出に多く使われてきた。

一方，超音波エコー法においては，方位方向の精度は送 受波器の開口の大きさと使用する超音波の波長の比によっ て決まる。したがって, 超音波センサは方位方向の精度が 悪い。これが従来の伝統的な超音波センサの最大の問題点 である。

超音波センシングにおけるもう一つの大きな問題は，反 射波の干涉である，超音波を反射させる物体は，色々な形 状を持ち，表面状態も一様ではない。このため，検出すべき 対象の物体から反射し受波器で観測される超音波は色々な 反射点からの波が重ね合わされて不規則に干渉したものと なる。したがって，運が悪いと反射物体が存在するにもか かわらずそれがほとんど検出されないことがある。これは レーザにおけるスペックルノイズと同じ現象である。すな
わち，送受波器を動かして空間を走査すると，反射物体の詳 細な形状とは独立のランダムな縞模様が観測される. 光を 用いる観察では波長が短いため，带域が極めて狭いレーザ 光を用いたときにのみスペックルノイズが問題となる。し かし，空気中の超望波センシングでは波長が長いため，か なり広帯域の超音波を用いてもこの現象が無視できない．

一方，対象物の表面が規則的なときは，検出される反射 波も規則的に干涉し，特別な性質が出現する．特に重大な 現象は，多くの物体の表面で，波は鏡面のように反射する ことである．波が物体に当たるとき，その表面に波長の長 さオーダの凸凹がなければ，その物体は散乱体とはならな い.したがって，屋内に存在する物体は，通常，超音波に 対してはほとんど「鏡面」として働く．表面が滑らかな物 体が送受波器に対して斜めの向きを持つと，超音波はその 表面で全反射し送信器の方向へは戻らないため, 検出でき ない。この性質は超音波を用いる上で極めて重大な物理的 性質である。

超音波パルスエコー法の限界や問題点は，いずれも，超 音波が空気中を伝わる波動であるという物理的性質に起因 する．従来から，レーダで用いられている開口合成などの 波の性質を利用した情報処理手法を超音波によるセンシン グに適用し，これらの問題を克服しようとする試みが行わ れてきた。しかしそれでは，空気中の超音波センシングに おける固有の問題は解決せず, 従来のアプローチが成功し たとはいいがたい。

今でもロボティクスにおける超音波センサといえば，数 十年前と同じく通常のパルスエコー法を指しているのが現 状である。

\section{3. ロボット用超音波センシングに関する最近の話題}

超音波センシングは，ここ20 年を見ても，視覚などに 比べてそれ程大きな進歩がなく，今でも従来と同様なセン シング法が使われているのが現実である．その中で従来の 限界を突破しようとするいくつかの試みについて以下で述 ベる。

\section{1 超音波パルスの広帯域化}

パルスエコー法では, 通常, 反射波の波頭（リーディン グエッジ）を検出するため, 超音波パルスの持続時間が直 接センサの精度となるわけではない. しかし, パルスが狭 帯域でその持続時間が長いと, 近くにある複数の反射物体 の分解は不可能であり, また上に述べた干渉が大きな問題 となる.

このパルス波の持続時間を減らすには，トランスデュー サの機械的な共振特性をなくして，これを広帯域化するこ とである。そのためにはトランスデューサとして高分子フィ ルムによるコンデンサ，または，压電特性を有する高分子 フィルムが用いられる．高分子フィルムを用いると形状を 


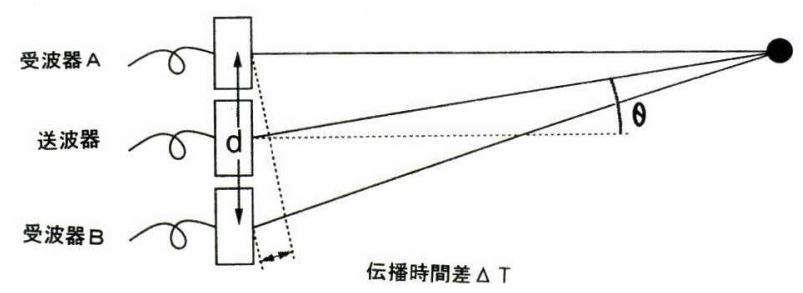

(a) 反射物体の方位

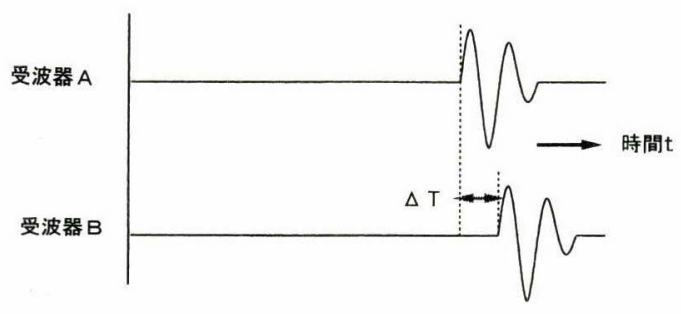

(b) 反射波形の時間差

図 1 二つの受信機が検出する反射波の時間差による精確な反 射方位測定

自由にでき，送受波器を空間的に並べたトランスデューサ アレーを作りやすいという特長もある。しかし，共振特性 を持なないことはそれ自体感度が低いということを意味す る。したがって, 遠方からの反射が雲囲気の雑音に埋もれ てしまわないように, 感度の高いトランスデューサや増幅 器の工夫が必要である。

大きな反射波を得るためには，強いエネルギーを持つ音 波のパルスを発射すればよい。しかし, 空気中で可能な音 圧の最大值は 1 気圧であり，そのような波は普通には伝播 しない.このため送波器としてパルスを用いる限り，空中に 送信できる超音波のエネルギーには限りがある。それを解 決して, 大きい音圧のパルスを発射するのと等価な効果を 得るのが, 時間的に分散させたエネルギーを空中に放射し, 後で反射波を信号処理して等価的に大きなエネルギーのパ ルスを発射したのと同じ反射信号を得る方法である。この 代表例は，時間とともに送信する周波数を牵引する CTFM 法である。この方法では，チャープ波を用いると送信波と 反射波の周波数の差違が反射時間になる。したがって，各 時刻の送受波の周波数の差を検出し, 差周波数ごとに平均 することによって SN 比の良い等価的なパルスエコー信号 を得ることができる $[1]$.

\section{2 複数の受信器による反射物体方位の高精度計測}

超音波パルス法における最大の問題は反射物体の方位方 向の計測精度が悪いことである。しかし，反射点が，空間 中の 1 点であるとすれば, 受信機を複数置き, それらが計 測する反射時間の差をとることにより，反射点の方位を高 い精度で求めることができる(図 1 )。

いま, 二つの受信器の間隔を $d$ とし, 十分遠い反射点か

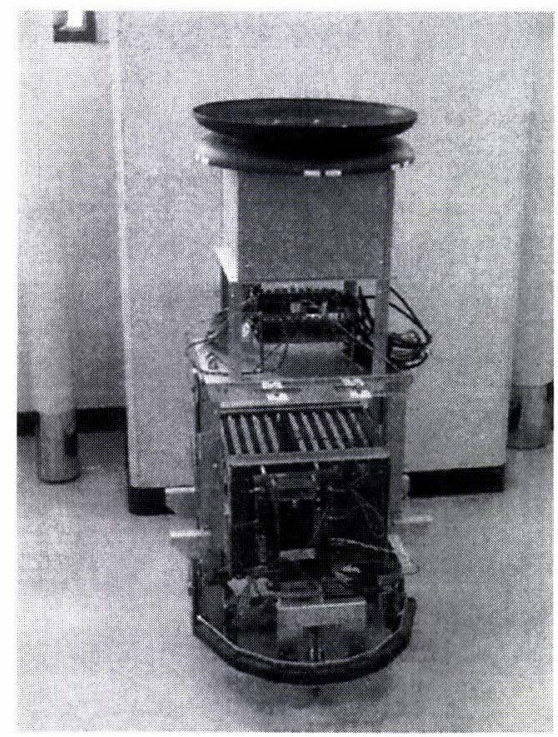

図 2 自律ロボット山彦に搭載したリアルタイムで高精度に全 方位の反射物体を計測するソナーリング

らの反射波を検出した時間差を $\Delta T$ とすると, 反射方向は

$$
\sin \theta=v_{0} \cdot \Delta T / d
$$

で求められる。したがって $d$ を $5[\mathrm{~cm}]$ とし， $\Delta T$ をマイ クロ秒の精度で求めれば, 反射点の方位は約 $0.4^{\circ}$ の精度で 求められる。

この方法では，物体からの反射時間の差を反射波のリー ディングエッジを検出することによって求められるため, 簡 単に実現できる。ただし，リーディングエッジを反射波の 振幅がある域值を超えた時間として求めると, 反射波のわ ずかな振幅の差により検出時間が 1 周期だけずれることが ある。超音波の 1 周期は, 時間としては大きく, $d=5[\mathrm{~cm}]$ とすると $40[\mathrm{kHz}]$ の波では, それによる誤差が約 $10^{\circ}$ と なってしまう。この誤差を防ぐために，原理的には波形を 取り込んで比較すればよい.しかし, 䛊差は波長の整数倍 に対応するものとなるので, 元長な受信器を準備して, 反 射波を検出し, それらの圥長なデータの中で矛盾なく求ま る $\theta$ を正しい反射点の方向であるとすることもできる $[2]$.

筆者らは，この原理により，30 個の受信器を円形配置し たソナーリングを用いて, 同時に全方向の超音波反射物体 を測定するシステムを開発している（図 2) [3].

\section{3 広帯域波を用いた反射物体の方向の検知}

広帯域の超音波卜ランスデューサを用いるとき, その指 向性は，超音波の周波数成分によって異なる。それにより， 広带域の電気パルスを送波器に与えたとき, 送波器から見 た方位によって空気中に放射される超音波の各周波数成分 の大きさが異なり，超音波の波形が異なる。この周波数依 存特性は, 受波器が超音波を検出した場合も同様である. したがって，受波器に得られる反射信号の波形を分析する 


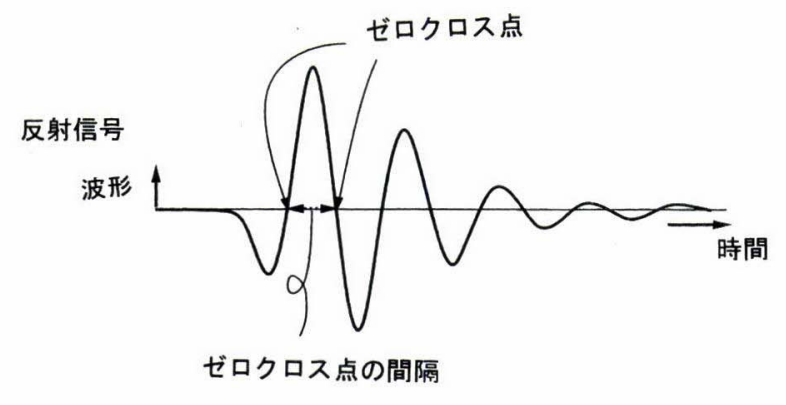

(a) 測定したゼロクロス間隔

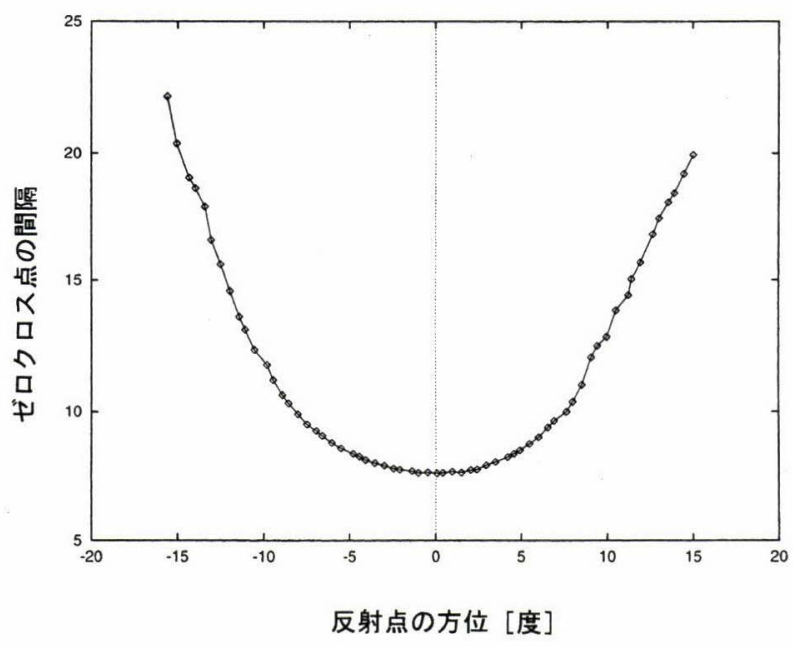

(b) 実測データ

図 3 反射点の方位と反射波信号のゼロクロス間隔 (半周期分) の関係（ポラロイド製トランスデューサを単一パルスで 駆動した場合)

ことによって，反射点の方向がトランスデューサの正面か らどれだけずれた方向かを知ることができる，具体的には， 反射波の中心周波数または反射波形のゼロクロス点の間隔 が，反射点の向きに依存する（図 3 ）。したがって，あらか じめ利用するトランスデューサに対して反射点の方位に対 するゼロクロス間隔を関数として測定しておけば，反射波 形から反射方位の情報を得ることができる [4].
4. む す び

実際に多く使われているロボットのための超音波センシ ングは,この 20 年間でほとんど進歩していない. その理由 は，伝統的な超音波パルスエコー法が極めて簡単でかつ優 れた物体検出能力を持つこと，および，それ以上の情報を 得ることに波の性質による原理的な難しさがあることの 2 点である。しかし, ロボットから離れた位置の状況を観測 するには，光や電磁波か音響的な波かのいずれかを用いる 以外に方法はない。 また, 超音波反射波形を丁寧に解析す ることで，今までにない情報を得ることはまだ可能なはず である．近年の情報処理・信号処理能力を本格的に適用し た新しい超音波センシングを検討する時期に来ているよう に思われる。

\section{参 考 文 献}

[1] L. Kay: "A Sonar Aid to Enhance Spatial Perception of the Blind: Engineering Design and Evaluation," The Radio and Electronic Engineer, vol.44, no.11, pp.605-627, 1974.

[2] 大矢晃久, 永島良昭, 油田信一：“超音波による壁面の法線方向の高 速測定”, 日本ロボット学会誌, vol.13, no.5, pp.700-703, 1995.

[3] 矢田晃子, 大矢晃久, 油田信一: “高速·高精度に反射点群を計測可 能なソナーリングシステム”, 日本ロボット学会誌, vol.17, no.8, pp.1173-1182, 1999.

[4] T. Yata, L. Kleeman and S. Yuta: "Fast-Bearing Measurement with a Single Ultrasonic Transducer," Robotics Research, vol.17, no.11, pp.1202-1213, 1998.

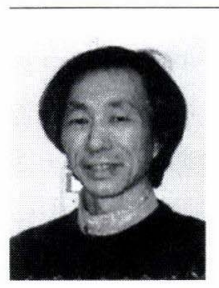

油田信一（Shin'ichi Yuta）

1948 年 3 月 28 日生. 1970 年慶應義塾大学 工学部電気工学科卒業. 1975 年同大学大学院 修了 (工学博士). 東京農工大学を経て, 1978 年加筑波大学. 現在, 同大学機能工学系教 授で, 2002 年度から機能工学系長. 20 年以 上にわたって自律移動ロボットの研究を続け ている。1983 年のロボット学会の発足に参加し, 第 1 期の庶務 担当理事を務めた。ほかに, IEEE (Fellow), 計測自動制御学 会等の会員. 